\title{
IMPACT OF EXPORTS AND IMPORTS ON THE ECONOMIC GROWTH IN BURUNDI
}

\author{
Wu Jiying ${ }^{\mathbf{a}}$ \\ ${ }^{a}$ School of Finance and Economics, Department of Statistics, Jiangsu University, Zhenjiang 212013, \\ PR China. \\ Niyonsaba Eric*a \\ ${ }^{a}$ School of Finance and Economics, Department of Statistics, Jiangsu University, Zhenjiang 212013, \\ PR China.
}

Blessed Kwasi Adjei ${ }^{a}$

${ }^{a}$ School of Finance and Economics, Department of Statistics, Jiangsu University, Zhenjiang 212013, PR China.

Article DOI: $\underline{\text { https://doi.org/10.36713/epra5265 }}$

\begin{abstract}
This paper investigated the impact of exports and imports on the economic growth in Burundi. To achieve this purpose, annual data for the periods between 1989 and 2018 were tested. The study used Granger Causality and Johansen Cointegration approach for long-run relationship Using Augmented Dickey-Fuller (ADF) and Phillip-Perron (PP) stationarity test, the variable proved to be integrated of the order I(1) at first difference. Johansen and Juselius Co-integration test was used to determine the presence or otherwise of a co-integrating vector in the variables. To find out the direction of causality among the variables, at least in the short-run, the Pairwise Granger Causality was carried out. Exports were found to Granger Cause imports. The results show that there is unidirectional causality between exports and imports. These results provide evidence that growth in Burundi was propelled by a growth-led import strategy as well as export-led import. Imports are thus seen as the source of economic growth in Burundi.
\end{abstract}

KEYWORDS: Co-integration, Granger causality; Exports; Imports; Economic growth, Burundi.

\section{INTRODUCTION}

With a population of 11.18 million in 2018 , crowded into a tiny area in the Great Lakes region in Central Africa, Burundi is a small, land-locked country with exports dominated by coffee (91\% of total exports in $1976,70 \%$ in average from 1995 to 2001). The top export destinations of Burundi are the United Arab Emirates, the Democratic Republic of the Congo, Pakistan, India and Belgium-Luxembourg. ${ }^{1}$ Net exports have been a drag on growth, primarily because of a

\footnotetext{
${ }^{1}$ Source: WITS UN Comtrade
}

narrow export base (partly because of the country being landlocked) and the need to import a large proportion of inputs that are not available in the country (Word Bank, 2018).

Burundi's external accounts remain vulnerable, with a sharp rise in the current account deficit estimated at $19.2 \%$ of GDP in 2018 , up from $11.3 \%$ in 2017. This deterioration is due to a downturn in exports, an increase in imports, and cuts in international transfers to NGOs. Foreign exchange pressures have continued, with a sharper drop in foreign exchange reserves and negative repercussions on imports. 


\section{EPRA International Journal of Economic Growth and Environmental Issues- Peer Reviewed Journal}

ISSN: 2321-6247

Volume: 8| Issue: 2| September 2020 | Journal DOI : 10.36713/epra0713 | SJIF Impact Factor (2020): 8.007

International reserves covered just 0.9 months of imports in December 2018

The rise of ODA (Official Development Assistance) to Burundi, starting from 2006, was often compensated by increases in imports, thereby affecting the country's trade balance. In addition, a low domestic savings rate (2-3 percent of GDP (Gross Domestic Product) in 2014) resulted in high dependence on foreign savings, which are typically associated with increased imports. Unfortunately, Burundi has not made progress on export diversification because coffee and tea remain the main exported products, accounting for more of total exports since the 2000s. The top import origins of Burundi are China $(\$ 111 \mathrm{M})$, India $(\$ 103 \mathrm{M})$, Saudi Arabia $(\$ 62.4 \mathrm{M})$, Tanzania $(\$ 56.2 \mathrm{M})$ and Kenya (\$50.4M) ((IFC), 2018).

It has been theoretically indicated that both export and import may play a crucial role in economic development. The theoretical and empirical studies mainly concentrate on either the relationship between export and growth or between import and growth or the association between export, import and economic growth. Exports and import of goods and services are seen as an engine of economic and social development for several reasons, including exports that require companies to innovate and improve to maintain market share (Saaed \& Hussain, 2015).

Exports ensure increased sales and profits. Alternatively, they reduce dependency on local markets since, in the event of expansion in foreign markets, the market base increases, leading to a reduction in local customers only. Otherwise, exports have the ability to minimize the impact of market volatility, by working in global markets, companies become more captive to economic changes, changing customer demands and seasonal fluctuations in the local economy (Bakari \& Mabrouki, 2017).

This paper develops a model for examining long-run relations between exports, imports and output growth for the economy of Burundi. The approach used here is well documented in the literature both in terms of methodology, modeling approach, and the number of countries studied. The importance of understanding these relationships is through the specification process by determining the direction of causality between imports, exports, and economic growth. In particular, we utilize the concepts of causality and co-integration to say something about the choice of development strategy by examining the growth path of the Burundian economy over the period 1989-2018.

The aim of this paper, therefore, is to econometrically investigate direct linkages among export, import and economic growth for Burundi by employing yearly data for the period 1989-2018. This work tries empirically to find in particular, an answer to the question of whether export leads to economic growth or whether import leads to economic growth or economic growth leads to export and import.

\section{LITERATURE REVIEW}

Different studies and researches were done by academics and policymakers for exports, imports and economic growth. The relationship between import, export and economic, has been a subject matter for a substantial body of empirical work. In any study of the aggregate economy, one of the key elements is the aggregate amount of goods and services produced over a certain period of time.

A large number of studies analyzed the ExportLed Growth (ELG) hypothesis using different econometric procedures ranging from simple OLS to multivariate co-integration but previous empirical studies have produced mixed and conflicting results on the nature and direction of the causal relationship between export growth and output growth.

Saaed \& Hussain (2015) investigated the impact of imports and exports on the economic growth of Tunis from 1977-2012. His paper employed Granger causality and Johansen's co-integration approach for the long-run relationship. While using Phillip-Perron (PP) and the augmented Dickey-Fuller (ADF) for stationarity test, the variable showed to be joined of the order one I (1) at the first difference. The study showed that economic growth was found to follow Granger causality for both imports and exports. The findings also indicate that there is unidirectional causality among imports and exports and between exports and economic growth.

Shihab et al., 2014; Shujaat (2012) examined their studies on the causal relationship between exports and economic growth in Pakistan and Jordan respectively. Both studies used Granger causality to determine the direction of the relationship between the two variables during the study period. Their studies indicated that there is a causal relationship between economic growth and exports

Zahoor (2012) proved that the explanatory variable (export) has a positive and significant impact on the economy of Pakistan. The results also showed that international trade may play an important role to enrich the economy of Pakistan. Mushfica (2015) revealed that the impact of export on economic growth was found as positive and an opposite scenario is investigated in the case of import. Ismail, Zaman, Atif, Jadoon, \& Seemab (2010) examined a long-run relationship between the variables (export and GDP) has been found. The ECM (error correction model) has been applied to the streamline of the variables on 
economic growth. Rai \& Purvashree (2015) showed that there is a positive relationship between growth rate and exports.

Bakari \& Mabrouki (2017) investigated the relationship between exports, imports, and economic growth in Panama, annual data for the periods between 1980 and 2015 were tested using the Johansen cointegration analysis of Vector Auto Regression Model and the Granger-Causality tests. According to their result of the analysis, it was determined that there is no relationship between exports, imports and economic growth in Panama. On the other hand, they found that there is strong evidence of bidirectional causality from imports to economic growth and exports to economic growth

Kotishwar (2020) their paper shows that Short-run causality result shows the presence of short-run causality between exports, domestic investment and exchange rate to GDP, running from the variables to GDP. Azeez, Dada, \& Aluko (2014) opined that international trade has a significant and positive impact on economic growth. Their result shows a positive relationship between imports, exports and openness on the economy.

In their research, Abdullahi et al. (2016) found that import has a positive but insignificant impact on GDP growth. Foreign exchange has a negative impact on GDP growth. Therefore, the study concluded that exports impact positively on the economic growth of West Africa and recommended that West African countries should encourage indigenous enterprises for export promotion and import substitution.

Ahamad (2018) found that international trade (export and import) has a significant positive impact on economic growth (GDP) in Bangladesh and international trade is strongly positively correlated with economic growth (GDP) in Bangladesh.

Lawal \& Ezeuchenne (2017) showed that there is a long-run relationship between international trade and economic growth, import and trade openness are both insignificant in the short-run but significant in the longrun while export and balance of trade are significant in both the short and long-run. The granger causality test showed that economic growth is independent of imports, exports and balance of trade but economic growth is unidirectional with trade openness. Agbo (2018), the results of their study showed that there is a significant impact of Export trade on the Nigerian economic growth.

Hussain (2014) examined the Granger Causality between economic growth (GDP), exports and imports in Pakistan over the period 1976-2011. Granger causality and co-integration tests were employed in the empirical analysis, using Augmented Dickey-Fuller
(ADF) and Phillip Perron (PP) tests. The variables proved to be integrated into the order I (1) at first difference. The Johansen and Juselius Co-integration test was used to determine the presence or otherwise of a co-integration vector in the variables. There was a bidirectional causality between GDP and exports. More interestingly, there was no significant causality between exports and imports growth.

Muhammad, Quddus, \& Ikram (2005) examined if export and GDP are co-integrated and they found that exports affect GDP. A positive relationship running from export to economic growth is suggested by the test results for the long-run period.

According to Saaed \& Hussain (2015) the export-led growth hypothesis (ELGH) assumes that export advancement is one of the key indicators of growth. It encourages the overall progress of countries can be achieved not only by mounting the quantity of manpower and investment within the economy, but also by increasing exports. Another relationship of causality from growth to export is called growth-led exports and it tells that there is unidirectional causality from economic growth to exports but not vice versa. There is also a possibility of two ways causality links from exports to growth and from growth to exports.

Li, Chen, \& Wang (2010) did co-integration analyses with the data of import, export and economic growth and the results suggest that the growth of imports greatly promoted economic growth of Jiangxi province China, while that of export performed the opposite one. Ali, Yassin, Ali, \& Dalmar (2018) investigated the impact of exports and imports on the economic growth of Somalia over the period 1970-1991. They applied econometric methods such as the OLS (Ordinary Least Squares) technique. The Granger Causality and Johansen Co-integration tests were also used for analyzing the long-term association. It was found that economic growth does not Granger Cause Export but was found that export Granger Cause GDP. So, this implies that there is unidirectional causality between exports and economic growth. Also, there is a bidirectional Granger Causality between import and export.

\section{DATA, METHODOLOGY AND MODEL SPECIFICATION 4.1 Data source}

The analysis utilized in this study covers the annual time series of 1989 to 2018 or 30 observations which should be sufficient to capture the short-run and long-run correlation between variables (Export, Import and economic growth) in the model.

The data set consists of observation for GDP, exports of goods and services (current US\$), and 
imports of goods and services (current US\$). All data set are taken from World Development Indicators 2020 (World Bank, 2020).

\subsection{Methodology}

This study employed the co-integration and error correction modeling technique as the estimation methodology. The entire estimation procedure consists of 5 steps: first, unit root test; second, co-integration test; third, the ECM estimation, forth Granger Causality and fifth VAR stability model.

\subsection{Model Specification}

This study examines the causal relationship between Economic growth, Export and Import, in Burundi. Granger-causality test in Vector Error Correction Model (VECM) framework is used to look at the causal relationship among Economic growth, Export and Import in Burundi.

The primary model showing the causal relationship among Economic growth, Export and Import in Burundi can be specified thus:

GDP $_{\mathrm{t}}=\mathrm{f}$ (exports, imports).

(1)

The log-linear econometric format of the function can also be represented thus:

$\begin{aligned} \log (G D P)_{t}=\beta_{0} & \left.+\log \beta_{1} \text { (export) }\right)_{t} \\ & +\log \beta_{2} \text { (import) } t \\ & +\varepsilon_{t}\end{aligned}$

Where: $\quad-\beta_{0}$ : The constant term.

- $\beta_{1}$ : coefficient of a variable (exports)

- $\beta_{2}$ : coefficient of a variable

(imports)

- $\mathrm{t}$ : The time trend.

- $\varepsilon_{t}$ : The random error term assumed

to be normally, identically and independently distributed.

The strength or validity of the OLS method depends on the accuracy of assumptions. During this study, the Gauss Markov assumptions are used and they include that the variables (GDP, export and import) are linearly co-related, the estimators $\beta_{0}, \beta_{1}$ and $\beta_{2}$ ) are unbiased with an expected value of zero i.e., $\mathrm{E}\left(\varepsilon_{t}\right)=0$, which implies that on average the errors cancel out each other. The procedure involves specifying the dependent and independent variables; in this case, GDP is the dependent variable while export and import are the independent variables.
This paper is based on the following hypotheses to test the causality and co-integration between GDP, export and import:

(i) There is bi-directional causality between GDP growth and export and Import in Burundi,

(ii) There is unidirectional causality between the three variables in Burundi,

(iii) There is no causality between GDP and export and import in Burundi,

(iv) There exists a long-run relationship between GDP and export and import in Burundi.

\section{EMPIRICAL ANALYSIS 5.1 Tests for Integration}

At this step, it is important to evaluate the stationary of the main variables and to determine the order of their integration for each of them. This implies testing the order of integration of the individual series considered. Several procedures for the test of the order of integration have been developed. The most popular ones are the Augmented Dickey-Fuller (ADF) test and the Phillip-Perron (PP) test.

The Augmented Dickey-Fuller test relies on rejecting a null hypothesis of the unit root (the series are nonstationary) in favor of the alternative hypotheses of stationarity. The tests are conducted with an intercept for each of the series. The tests are conducted without a deterministic trend or with an intercept for each of the series.

It is very important to know about the stationary properties of variables. Thus, the unit root test is applied to examine if the null hypothesis has a unit root or not.

The general form of the Augmented Dickey-Fuller test is estimated by the following regression:

$\Delta Y_{t}=\alpha_{0}+\alpha_{1} Y_{t-1}+\sum_{i=1}^{n} \alpha_{2} \Delta Y_{i}+\varepsilon_{t}$

Where: $\mathrm{Y}$ is a time series, $\mathrm{t}$ is a linear time trend, $\Delta$ is the first difference operator, $\alpha_{o}$ is a constant, $n$ is the optimum number of lags in the dependent variable and $\varepsilon_{t}$ is the random error term.

The general form of the PP test equation is then:

$\Delta Y_{t}=\alpha_{0}+\alpha_{1} Y_{t-1}+\varepsilon_{t}$

Where $\Delta$ is the first difference operator. 
EPRA International Journal of Economic Growth and Environmental Issues- Peer Reviewed Journal

ISSN: 2321-6247

Volume: 8| Issue: 2| September 2020 | Journal DOI : 10.36713/epra0713 | SJIF Impact Factor (2020): 8.007

Table 1: Unit Root Tests (ADF, PP) on $\log ($ GDP), $\log$ (exports) and $\log$ (imports) :1989 to 2018

\begin{tabular}{|c|c|c|c|}
\hline Variables & ADF & PP & $\begin{array}{c}\text { Order of } \\
\text { integration }\end{array}$ \\
\hline & Level $\Delta$ & Level $\Delta$ & $\mathrm{I}(1)$ \\
\hline $\log (\mathrm{GDP})$ & 0.9968 & 0.9893 & $\mathrm{I}(1)$ \\
\hline $\log ($ exports) & $0.0076^{* * *}$ & $0.0066^{* * *}$ & 0.6080 \\
\hline $\log$ (imports) & 0.8575 & $0.0000^{* * *}$ & $\mathrm{I}(1)$ \\
\hline
\end{tabular}

*** denotes significant at 1\% level respectively. and in PP test it is based on NeweyWest using Bartlett kernel (Source: Eviews version 10 Compiled data).

The results of Table 1 show that all variables are nonstationary in levels but stationary in the first difference. Since the variables are I (1) the next step is to test if they are co-integrated using the Johansen full information maximum likelihood.
Once the order of integration of the studied variables is in first differentials, we will determine the co-integration between them. But before this step, one must fix he number of delays existing in this estimate. To achieve this, we will apply the VAR Lag order selection criteria method.

Table 2: Lag Order Selection Criteria

\begin{tabular}{ccccccc}
\hline \hline Lag & LogL & LR & FPE & AIC & SC & HQ \\
\hline \hline 0 & 54.52530 & NA & $5.06 \mathrm{e}-06$ & -3.680379 & -3.537642 & -3.636743 \\
1 & 114.6658 & 103.0980 & $1.32 \mathrm{e}-07$ & -7.333270 & $-6.762325^{*}$ & -7.158726 \\
2 & 128.3631 & $20.54605^{*}$ & $9.69 \mathrm{e}-08^{*}$ & $-7.668796^{*}$ & -6.669643 & $-7.363345^{*}$ \\
\hline \hline
\end{tabular}

* indicates lag order selected by the criterion

LR: sequential modified LR test statistic (each test at 5\% level)

FPE: Final prediction error

AIC: Akaike information criterion

SC: Schwarz information criterion

HQ: Hannan-Quinn information criterion

Source: Eviews version 10 Compiled data.

Table 2 that LR, FPE, AIC and HQ statistics are chosen lag 2 for each endogenous variable in their autoregressive and distributed lag structures in the estimable VAR model. Therefore, lag 2 is used for estimation purpose. Therefore, at this moment, we are ready to process the existing co-integration number.

\subsection{Co-integration Analysis: Johansen Test}

To determine the number of co-integrations existing in our situation, we use the most effective and suitable test, which is the Johansen test.

Table 3: Co-integration Test

\begin{tabular}{lcllc}
\hline \hline Hypothesized No. of CE(s) & Eigenvalue & Trace Statistic & 0.05 Critical Value & Prob.** \\
\hline \hline None ${ }^{*}$ & 0.592290 & 29.84607 & 29.79707 & 0.0494 \\
At most 1 & 0.172838 & 5.621711 & 15.49471 & 0.7397 \\
At most 2 & 0.018288 & 0.498343 & 3.841466 & 0.4802 \\
\hline \hline
\end{tabular}

Source: Eviews version 10, Compiled data.

Trace test indicates 1 co-integrating equation at the 0.05 level

According to table 3, the variables are co-integrated or have a long-run relationship. Then we can run restricted VAR, which is the VECM model. 
EPRA International Journal of Economic Growth and Environmental Issues- Peer Reviewed Journal

ISSN: 2321-6247

Volume: 8| Issue: 2| September 2020 | Journal DOI : 10.36713/epra0713 | SJIF Impact Factor (2020): 8.007

5.3 VAR estimation: The aim of the model estimation is to point out and see if there are effects between the independent variables that are negative or positive on the dependent variable.

Table 4: Vector Auto-regression Estimates

\begin{tabular}{lccc}
\hline \hline & $\log ($ GDP $)$ & $\log$ (exports) & $\log$ (imports) \\
\hline \hline $\log$ (GDP) (-1) & 1.166427 & -0.257151 & 0.457247 \\
& $(0.24689)$ & {$[0.66799)$} & {$[0.68011)$} \\
& {$[4.72440]$} & {$[-0.38496]$} & {$[0.67231]$} \\
\hline $\log$ (GDP) (-2) & -0.251182 & 0.392920 & -0.137875 \\
& $(0.29812)$ & {$[0.80659)$} & {$[0.82123)$} \\
& {$[-0.84254]$} & {$[0.48713]$} & {$[-0.16789]$} \\
\hline $\log$ (exports) (-1) & -0.165221 & -0.064400 & -0.320057 \\
& $(0.08157)$ & {$[0.22068)$} & {$[0.22469)$} \\
\hline $\log$ (exports) (-2) & {$[-2.02560]$} & {$[-0.29182]$} & {$[-1.42445]$} \\
& -0.048633 & 0.059799 & -0.298339 \\
& $(0.09210)$ & {$[0.24919)$} & {$[0.25371)$} \\
\hline $\log$ (imports) (-1) & {$[-0.52803]$} & {$[0.23997]$} & {$[-1.17590]$} \\
& 0.104676 & 0.348891 & 0.985529 \\
& $(0.09354)$ & {$[0.25307)$} & {$[0.25766)$} \\
\hline $\log$ (imports) (-2) & {$[1.11908]$} & {$[1.37863]$} & {$[3.82486]$} \\
& 0.137605 & 0.405804 & 0.182610 \\
& $(0.12347)$ & {$[0.33407)$} & {$[0.34013)$} \\
\hline C & {$[1.11445]$} & {$[1.21474]$} & $0.53689]$ \\
\hline \hline
\end{tabular}

Standard errors in 0 and t-statistics in []

Source: Eviews version 10, Compiled data.

The results of the VAR model estimate show that the variable that indicates exports has a negative effect on GDP, but it does not have a significant probability. On the other hand, the variable that designates imports has a positive effect on GDP, but it also has a probability that it is not significant.

\subsection{The Error Correction Model}

The aim of the error correction model is to show the speed of adjustment from the short-run equilibrium to the long-run equilibrium state. If the co-efficient of the parameter is great then the speed of adjustment of the model from the short-run to the long-run is high. We represent equation (2) with an error correction form that allows for the inclusion of long-run information therefore, the Error Correction Model (ECM) can be formulated as follows: 
$\triangle G D P_{t}=$ $\sum_{i=1}^{n} \alpha_{0} \Delta G D P_{t-i}+\sum_{i=1}^{n} \alpha_{1} \Delta$ exports $_{t-i}+\sum_{i=1}^{n} \alpha_{2} \Delta$ imports $_{t-i}+\delta_{1} E C 1_{t-1}+\varepsilon_{1 t}$

where $\Delta$ is the difference operator; $\mathrm{n}$ is the numbers of lags, $\alpha_{1}$ and $\alpha_{2}$ are short-run coefficients to be estimated, $E C 1_{t-1}$ represents the error correction term derived from the long-run cointegration relationship and $\varepsilon_{1 t}$ the serially uncorrelated error terms in equation (5).

Equation: $\mathrm{D}(\log (\mathrm{GDP}))=\mathrm{C}(1) *(\log (\mathrm{GDP})(-1)+5.52749310368 * \log ($ exports $)(-1)-5.7964958724 * \log (\mathrm{imports})(-$ 1) -4.06747683$)+\mathrm{C}(2) * \mathrm{D}(\log (\mathrm{GDP})(-1))+\mathrm{C}(3) * \mathrm{D}(\log (\mathrm{GDP})(-2))+\mathrm{C}(4) * \mathrm{D}(\log (\operatorname{exports})(-1))+$ $\mathrm{C}(5) * \mathrm{D}(\log ($ exports $)(-2))+\mathrm{C}(6) * \mathrm{D}(\log ($ imports $)(-1))+\mathrm{C}(7) * \mathrm{D}(\log ($ imports $)(-2))+\mathrm{C}(8)$

Table 5: Error Correction

\begin{tabular}{lllll}
\hline \hline & Coefficient & Std. Error & t-Statistic & Prob. \\
\hline \hline $\mathrm{C}(1)$ & -0.052789 & 0.019244 & -2.743182 & 0.0081 \\
$\mathrm{C}(2)$ & 0.435456 & 0.258989 & 1.681367 & 0.0982 \\
$\mathrm{C}(3)$ & -0.514418 & 0.278073 & -1.849937 & 0.0695 \\
$\mathrm{C}(4)$ & 0.007186 & 0.108640 & 0.066143 & 0.9475 \\
\hline \hline & Coefficient & Std. Error & t-Statistic & Prob. \\
$\mathrm{C}(5)$ & 0.017654 & 0.087749 & 0.201189 & 0.8413 \\
$\mathrm{C}(6)$ & -0.139366 & 0.116346 & -1.197859 & 0.2359 \\
$\mathrm{C}(7)$ & 0.037699 & 0.134230 & 0.280853 & 0.7798 \\
$\mathrm{C}(8)$ & 0.015925 & 0.008315 & 1.915164 & 0.0605 \\
\hline \hline
\end{tabular}

Source: Eviews version 10, Compiled data.

\subsection{Granger Causality Results}

Since there is co-integration between the variables, the next step is to test for the direction of causality using the vector error correction model (VECM). The presence of a co-integrating vector allows for the use of a vector error correction model to test causality. The results of the Granger causality test are presented in Table 5 shows that there is weak evidence suggesting that the direction of causality runs from exports to GDP and from imports to GDP for the case of Burundi, but import granger causes export. The results show that there is unidirectional causality between imports and exports but export does not Granger cause GDP and import does not Granger cause GDP. The coefficient of the lagged error correction term for all models is positive and not significant and this implies that there is no long-run causal relationship between imports and exports in Burundi. 
EPRA International Journal of Economic Growth and Environmental Issues- Peer Reviewed Journal

ISSN: 2321-6247

Volume: 8| Issue: 2| September 2020 | Journal DOI : 10.36713/epra0713 | SJIF Impact Factor (2020): 8.007

Table 6: Result of Granger Causality

\begin{tabular}{lccc}
\hline \hline Null Hypothesis: & Obs & F-Statistic & Prob. \\
\hline \hline $\log$ (imports) does not Granger Cause log(GDP) & 28 & 1.11918 & 0.3437 \\
$\log ($ GDP) does not Granger Cause $\log ($ imports) & & 0.43323 & 0.6536 \\
\hline \hline $\log ($ exports) does not Granger Cause log(GDP) & 28 & 0.83834 & 0.4452 \\
$\log$ (GDP) does not Granger Cause log(exports) & & 3.00692 & 0.0692 \\
\hline \hline $\log$ (exports) does not Granger Cause log(imports) & 28 & 2.63966 & 0.0929 \\
$\log$ (imports) does not Granger Cause log(exports) & & 8.75344 & 0.0015 \\
\hline \hline
\end{tabular}

Source: Eviews version 10, Compiled data.

\subsection{White Heteroscedasticity Test}

We have to check the model efficiency, whether the model has heteroscedasticity. We check for Heteroscedasticity we find that the model free from heteroscedasticity when F-statistic corresponding to $p$ - value $=0.0970$ and obs $* \mathrm{R}$-squared corresponding to $p$ value $=0.0925$ greater than 0.05 , meaning that the residuals are free from Heteroscedasticity.

Table 7: White Heteroscedasticity Test

\begin{tabular}{llll}
\hline \hline F-statistic & 2.547089 & Prob. F(2,27) & 0.0970 \\
Obs*R-squared & 4.761777 & Prob. Chi-Square(2) & 0.0925 \\
Scaled explained SS & 6.433435 & Prob. Chi-Square(2) & 0.0401 \\
\hline \hline
\end{tabular}

Source: Eviews version 10 Compiled data.

\section{DISCUSSION AND CONCLUSION}

This study aimed to determine the relationship between exports, imports, and economic growth of Burundi in the period 1989 to 2018 . The co-integration test, VAR model, and Granger causality tests are used here to look into the relationship between these three variables. The unit root properties of the data were examined using the Augmented Dickey-Fuller test (ADF) and Phillips Perron test (PP) after that the cointegration and causality tests were conducted. The error correction models were also estimated to examine the short -run and long-run between GDP and Exports.

The finding is cleared that export, import, and GDP are found stationary at the first differences. Thus, the variables were found to be integrated of order one. The co-integration test confirmed that GDP, export, and import are co-integrated, indicating or showing existence of a long-run equilibrium relationship between the variables (GDP, export, and import) confirmed by the Johansen co-integration test results.

The error correction models test confirmed that there exists short-run causality between GDP and imports and between export and import. The Granger causality test finally confirmed the presence of unidirectional causality or unidirectional relationship between imports to exports, but not the other way. From the causality test, the result show that exports and imports do not cause economic growth. These results indicate that exports and imports are presented and seen as a source of economic growth in Burundi.

The estimation of the VECM model shows that exports and imports do not affect Burundian economic growth.

Policy recommendation to the government, the government should discourage the importation except the capital goods that can be used in production not consumption. The government can impose strict restrictions such as quotas and increase in import tariffs because importation has a negative effect on the economic growth of Burundi. Also, the government should rise up its exportation because the trade balance is negative in Burundi. Government needs to take proper steps for improving exports to increase its economic growth.

\section{REFERENCES}

1. (IFC), I. F. C. (2018). ADDRESSING FRAGILITY AND DEMOGRAPHIC CHALLENGES TO REDUCE POVERTY AND BOOST SUSTAINABLE GROWTH. Report No. 122549-BI. 
2. Abdullahi, A. O., Safiyanu, S. S., \& Soja, T. (2016). International Trade And Economic Growth: An Empirical Analysis Of West Africa. IOSR Journal of Economics and Finance (IOSR-JEF), 7(2), 12-15. https://doi.org/10.9790/5933-07211215

3. Agbo Igwebuike, E., AGU RUPHINA, E., \& LOVETH OLUCHUKWU, E. (2018). Impact of International Trade on the Economic Growth of Nigeria. European Journal of Business and Management, 10(18), 22-30.

4. Ahamad, M. . H. (2018). Impact of International Trade on Economic Growth in Bangladesh. International Journal of Science and Research (IJSR), 7(11), 1624-1627.

5. Ali, A. A., Yassin, A., Ali, S., \& Dalmar, M. S. (2018). The Impact of Imports and Exports Performance on the Economic Growth of Somalia. International Journal of Economics and Finance, 10(1), $110-119$ https://doi.org/10.5539/ijef.v10n1p110

6. Azeez, B. A., Dada, S. O., \& Aluko, O. A. (2014). Effect of International Trade on Nigerian Economic Growth: The 21st Century experience. International Journal of Economics, Commerce and Management, II(10), 1-8.

7. Bakari, S., \& Mabrouki, M. (2017). Impact of Exports and Imports on Economic Growth: New Evidence from Panama. Journal of Smart Economic Growth, 2(1), 67-79.

8. Bank, W. (2020). World Development Indicators. https://databank.worldbank.org/source/worlddevelopment-indicators

9. Hussain, M. A. (2014). Economic Growth, Exports and Imports in Pakistan: Granger Causality Analysis. Journal of Business in Developing Nations, 13, 31-62.

10. Ismail, A., Zaman, K., Atif, R. M., Jadoon, A., \& Seemab, R. (2010). The Role of Exports, Inflation and Investment on Economic Growth in Pakistan. International Journal of Economics and Research IJER, 1(1), 1-9.

11. Javed, Z. H., Saif-ullaha, Qaiser, I., Mushtaq, A., \& Iqbal, A. (2012). Effects of International Trade On Economic Growth: The Case Study of Pakistan. International Journal of Academic Research in Progressive Education and Development, 1(2), 103-113.

12. Kotishwar, A. (2020). A Study on the Role of Exports and Imports in Indian Economic Growth. Gis Business, 15(4), 902-932. https://orcid.org/0000-0002-8027-3417

13. Lawal, E. O., \& Ezeuchenne, K. (2017). International Trade and Economic Growth in Nigeria. OSR Journal Of Humanities And Social Science (IOSR-JHSS), 22(6), 35-43. https://doi.org/10.9790/0837-2206083543

14. Li, Y., Chen, Z., \& Wang, X. (2010). An Empirical Study on the Contribution of Foreign Trade to the Economic Growth of Jiangxi Province, China. Scientific Research Publishing, 2010(June), 183-
187. https://doi.org/10.4236/ib.2010.22022

15. Muhammad, A., Quddus, \& Ikram, S. (2005). An Analysis of Exports and Growth in Pakistan. The Pakistan Development Review, 44 : 4 Par, 921937.

16. Mushfica, A. (2015). The impact of export and import on economic growth in Bangladesh. World Vision Research Journal, 9(1), 66-81.

17. Rai, S. K., \& Purvashree, J. (2015). Impact of Exports and Imports on Growth Rate of India: An Empirical Enquiry. Pacific Business Review International, 8(6), 53-58.

18. Saaed, A. A. J., \& Hussain, M. A. (2015). Impact of Exports and Imports on Economic Growth: Evidence from Tunisia. Scholarlink Research Institute Journals, 6(1), 13-21.

19. Shihab, R. A., Soufan, T., \& Shatha, A.-K. (2014). The Causal Relationship between Exports and Economic Growth in Jordan. International Journal of Business and Social Science, 5(3), 302-308.

20. Shujaat, A. (2012). Causality between Exports and Economic Growth: Investigating Suitable Trade Policy for Pakistan. Journal Eurasian, 5(10), 9198.

21. Word Bank. (2018). World Bank. https://databank.worldbank.org/source/worlddevelopment-indicators 